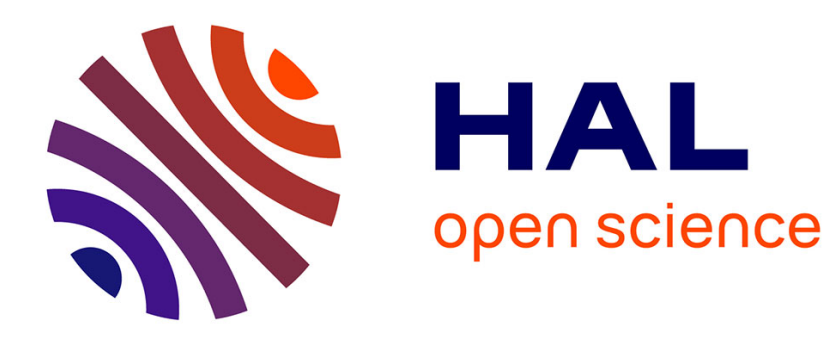

\title{
Conservation tillage in Turkish dryland research
}

Avci

\section{- To cite this version:}

Avci. Conservation tillage in Turkish dryland research. Agronomy for Sustainable Development, 2011, 31 (2), pp.299-307. 10.1051/agro/2010022 . hal-00930456

\section{HAL Id: hal-00930456 https://hal.science/hal-00930456}

Submitted on 1 Jan 2011

HAL is a multi-disciplinary open access archive for the deposit and dissemination of scientific research documents, whether they are published or not. The documents may come from teaching and research institutions in France or abroad, or from public or private research centers.
L'archive ouverte pluridisciplinaire HAL, est destinée au dépôt et à la diffusion de documents scientifiques de niveau recherche, publiés ou non, émanant des établissements d'enseignement et de recherche français ou étrangers, des laboratoires publics ou privés. 


\title{
Review article
}

\section{Conservation tillage in Turkish dryland research}

\author{
Muzaffer Avci* \\ Central Research Institute Field Crops (CRIFC), Agronomy Department, PO Box 226, Ankara, Turkey
}

(Accepted 3 May 2010) (Published online: 21 July 2010)

\begin{abstract}
Central Anatolian soils have high risk of erosion, degradation and intensive cultivation. Consequently, they are in danger of exhausting their agricultural use unless conservation agricultural practices are adopted. Conservation agriculture is a key tool in sustainable production systems throughout the world and is developed around soil management technology that minimizes soil disturbance, maximizes the soil cover and promotes crop diversity to offer benefits to farmers and to the environment. It has been particularly effective at sustaining crop production in semi-arid rain-fed regions such as the Central Anatolian soils, where potential evaporation exceeds precipitation during most months of the year, dry farming is extensively practiced, water and wind erosion is common, and proper application of water- and soil-conserving tillage technology is critical. The area under plow expanded its limits as the number of tractors in agriculture dramatically increased in the 1960s. This is the starting point for inappropriate use of the agricultural land. The conservation agricultural technologies, therefore, are of utmost importance for the region. Common farmers' practices of a fallow-wheat system in the central plateau of Turkey are incompatible with the conservation agriculture concept. The objective of this review is to re-evaluate the performances of the partial and full conservation tillage practices previously tried in the region. This review reached the following conclusions: (1) agreeing with the conservation principles, fall tillage as a primary operation in the fallow phase was found to be useless compared with leaving the land without tillage; (2) therefore, much research has focused on spring tillage as a primary operation and employed conventional, semi-conservative and conservative methods. Results showed that the conventional system, in addition to being ecologically unfriendly, is unprofitable as compared with other conservation practices regarding the updated cost analysis; (3) similarly, tillage depth in primary spring tillage was determined to be shallower than the depths currently practiced by farmers, in agreement with the conservation principles; (4) fallow tillage operations in summer to create dust mulch for eliminating soil moisture loss did not increase the crop yields and soil moisture as compared with chemical fallow; (5) no-till fallow was similar to the conventional clean fallow system in terms of moisture and yield levels. However, no-tillage resulted in $50 \%$ reduction in the cost of tillage besides its ecologically-friendly effects; (6) the existing dryland agricultural systems in the plateau should be transformed into or changed toward sustainable systems, although further research is required on residue and stubble management, and integrated weed control methods to drill the soil with high amounts of residue on the field.
\end{abstract}

dryland farming / summer fallow / erosion / stubble / straw / tillage / no-tillage / weed control

\section{Contents}

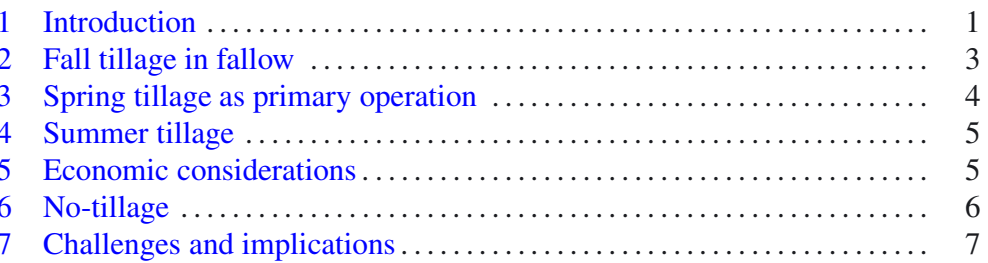

\section{INTRODUCTION}

Conservation tillage is variously defined around the globe. In the USA, the definition includes a minimum of $30 \%$ soil cover after planting to reduce soil erosion by water, or where soil erosion by wind is the primary concern, a minimum of $1120 \mathrm{~kg} \mathrm{ha}^{-1}$ of flat, small grain residue equivalent on the soil surface throughout the critical wind erosion period (CTIC, 2004). However, precise definitions of conservation tillage can

*Corresponding author: muzafavci@yahoo.com 


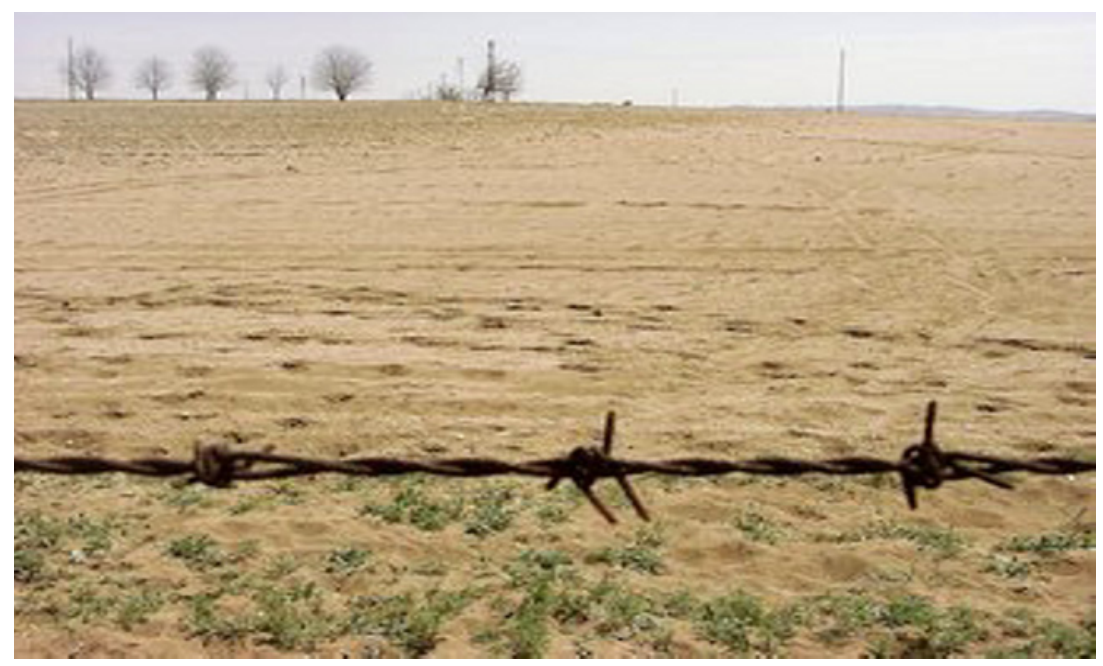

Figure 1. Field covered by sediments eroded by south winds (Lodos) in Central Anatolia.

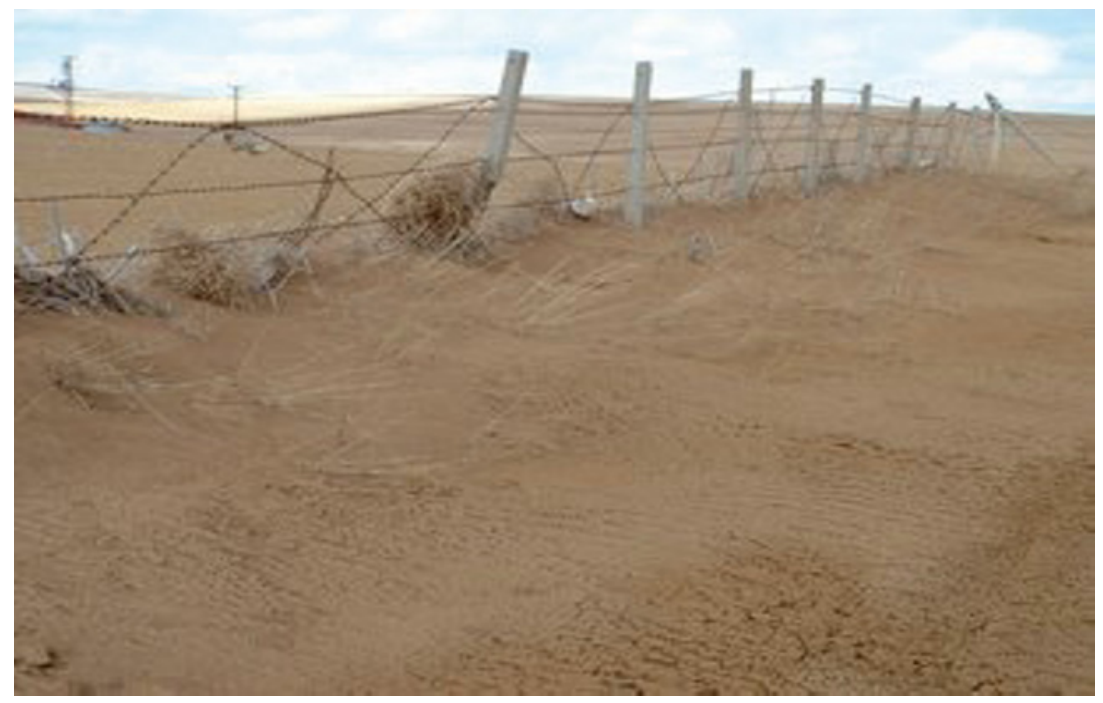

Figure 2. Post-winter scene of soils eroded by south winds (Lodos) in Central Anatolia, 2006.

only be made in the context of the crop species and varieties, soil types and conditions, and climates (Carter, 1994). Conservation agriculture is developed around soil management technology that minimizes soil disturbance, maximizes the soil cover and promotes crop diversity to offer benefits to farmers and to the environment.

Common agricultural practices in the fallow-wheat system in Central Anatolia are incompatible with the conservation agriculture concept. Surface soil has no residue cover and loses its aggregation and becomes dust as a result of frequent tillage operations during the 16 months of the fallow period. In addition to fallow fields, the planted fields have no crop residue cover and are under high risk of wind and water erosion during the growing period of 10 months, but especially immediately before and after drilling. Measures to protect soils from wind and water losses are the prerequisite for the sustainable use of the croplands. In Turkey, as the importance of water erosion is well known, wind erosion has been regarded as unimportant and confined to special areas such as Karapinar-Konya and İncesu-Kayseri. For the last 5 years, we have observed severe wind erosion (especially during the Lodos - south wind) in Central Anatolia during the winter months. Roadsides and sheltered fields are covered with the sediments eroded from open fields (Fig. 1). However, evidence of erosion is removed by rain or snowfall and soils then bear a resemblance to those affected by successive freezing and thawing events (Fig. 2). Soykan (1962) reported that the soils blown by wind accumulated in sheltered places and sometimes heaped up to the windows of the houses in Central Anatolia. He also emphasized the fact that soil erosion was started even by the gentle winds in the case of soils with no or little residue on them and low organic matter. Mutaf (1970) indicated that abrasion and eradication of young plants by wind and covering of planted fields with the eroded soil were regarded as ordinary events in 
Central Anatolia. Christiansen Veniger (1973) provided some photos emphasizing the wind erosion problems in the central plateau. In order to reduce the hazard of severe wind erosion, many researchers recommended reconsideration of the summer (clean) fallow practices which make the soil more vulnerable to wind erosion by successive summer tillage operations and construction of wind breaks (Beşkök, 1957; Beşkök, 1966; Hans-Johaim Spath, 1975; and Aydemir, 1975). Soil surface cover of living vegetation or crop residue is the simplest and surest way of reducing erosion. Small-stemmed residues such as wheat or barley create more friction with the wind than large-stemmed ones such as corn or sunflower stalks. Standing residue is more effective than lying residue to control wind erosion.

The crop residue cover reduces evaporation, and the standing stubble traps snow for extra soil moisture. At the same time, the crop residue reduces wind speed on the soil surface, and standing stubble anchors the soil, and traps the snow (MWPS-45, 1992).

Most soils require 30 percent ground cover to prevent wind erosion. For cereal crop residues, this is equivalent to about 900 to $1100 \mathrm{~kg} \mathrm{ha}^{-1}$ of residue. The best way to reduce water and wind erosion is to leave the crop residue on the soil surface. The amount of residue mulch reduces erosion to a different extent. Residue mulches of 1.24 and $2.47 \mathrm{tha}^{-1}$ minimized the loss of runoff water and soils on slopes of different lengths and steepness (Kramer and Meyer, 1969). While $2.0 \mathrm{t} \mathrm{ha}^{-1}$ reduced the loss by $80 \%$, a mulch rate of only $0.5 \mathrm{t} \mathrm{ha}^{-1}$ decreased the loss by $40 \%$ (Lattanzi et al., 1974). In another study, erosion of $0.56 \mathrm{tha}^{-1}$ and $1.12 \mathrm{t} \mathrm{ha}^{-1}$ mulch rates was less than $25 \%$ of erosion without mulch (Meyer et al., 1970).

In the central plateau, crop residue research was carried out on fallow fields by using treatments with and without stubble (burning). The effects of the treatments of stubble management on the fallow fields were evaluated on the next years' crop phase. Thus, wheat stubble left on the field caused 110 to $950 \mathrm{~kg} \mathrm{ha}^{-1}$ less soil and 3.5 to $20 \mathrm{~mm}$ less soil water losses during the fallow phase, and 17 to $25 \%$ more subsequent wheat yields than stubble burning (Ayday, 1980; Sayın, 1983).

Besides soil erosion control, the soil organic matter content is increased by leaving stubble on the soil surface. There is consensus that carbon sequestration potential is higher in humid temperate areas $(0.1$ to $0.5 \mathrm{t} \mathrm{C} / \mathrm{ha} / \mathrm{yr})$ than in semi-arid and tropical areas (0.05 to $0.20 \mathrm{t} \mathrm{C/ha/yr).} \mathrm{Palm} \mathrm{et} \mathrm{al.} \mathrm{(2000)}$ measured carbon stocks, losses and rates of accumulation in Brazil, Cameroon and Indonesia. They concluded that carbon accumulation rates are much higher in aboveground biomass (at least $2 \mathrm{t} \mathrm{C} / \mathrm{ha} / \mathrm{yr})$ than in soils $(0.2-0.6 \mathrm{t} \mathrm{C} / \mathrm{ha} / \mathrm{yr})$, and also indicate that tree-based agro-ecosystems, either plantation crops (e.g. oil palm, cacao and rubber agro-forests) or on smallholder farms, bring the greatest dividend, accumulating 3.0-9.3 t C/ha/yr (Sanchez et al., 1999; Sanchez and Jama, 2000). Rapid decomposition occurred when the stubbles were buried to $12 \mathrm{~cm}$ depth and almost all the stubbles were mineralized in 18 months of the fallow period. On the other hand, only $33 \%$ of stubbles were decomposed when they were kept on the soil surface for the same period (Özbek et al., 1976; Cogle et al., 1987). Thus, a substantial part (60-65\%) of the stubbles accumulates on the soil each year. Our observations also showed that no debris from the stubbles of the previous harvest can be seen on the field at the planting time of wheat. This clearly indicates that all the residue which was buried by the moldboard plow is decomposed during the fallow season.

The purpose of this study is to re-evaluate the performances of the conservation tillage practices previously studied in dryland conditions in view of the current socio-economic circumstances; and thereby shed light on the current and future research agenda by presenting the pros and cons of the practices.

\section{FALL TILLAGE IN FALLOW}

The earliest studies on soil tillage in the fallow phase were performed by Kıraç (1937) during the 1930s. In his studies, tillage practices were evaluated in terms of soil moisture conservation and nitrate accumulation as well as grain yield of wheat. Comparing his findings with those found in dryland areas of the USA, Kıraç discussed the results of fall tillage practices more prudently than his successors and tested various implements (moldboard plow, disc harrow and no-tillage) for the following expectations: (1) controlling the weeds and volunteers during the fall; (2) burying weed seeds and eliminating them after germination; (3) increasing the rainfall penetration into the soil; and (4) enrichment of soil organic matter. Unfortunately, the results were in contrast to his expectations and one to $15 \%$ yield increase was obtained with no-tillage in the fall. Further investigating fall tillage, Gerek (1968) compared tillage and no-tillage on wet (good tilth) and dry soils with the control (moldboard plow in March) treatment under slope and bottom soils. The 18 years of results showed that while there was not any yield difference among the treatments on dry soil, significant differences were detected on bottom soils in favor of tillage. The advantage of tillage on bottom soil can partly be attributed to successful weed control by tillage treatment because the weed problem is expected to be more severe on bottom soils than slope soils. Volunteer and weed seeds germinate easily in the wet soil until the winter months and then are eliminated by the fall tillage. Thus, the fall tillage operation can contribute much to the weed control in wet soils. In another study, tillage treatments consisting of different reduced tillage methods and the moldboard plow were compared in 16 locations in Central Anatolia. Fall, spring and summer tillage practices were evaluated separately. The results of the fall tillage, although statistical analysis was not performed, showed that the moldboard plow provided more average yield than a chisel, subsoiler and no-tillage. The moldboard plow was superior to the other methods in only one year of the research. Therefore, by referencing the previous research results, the authors concluded no difference among the tillage methods, and recommended no-tillage in the fall for the central plateau (Pehlivantürk et al., 1977). Dogan et al. (1977) tested various fall tillage methods in the plateau for three years. The results indicated that chisel plowing was superior to no-tillage and the subsoiler in terms of grain yield and moisture conservation. However, the yield difference was not found to be statistically significant. Therefore, they decided in favor of 
no-tillage. As a summary of fall tillage, it was concluded by all the research results that tillage practice in the fall did not make a difference. This conclusion supports the idea of conservation agriculture. Standing stubble keeps the snow in the fields, increases the infiltration capacity of the soil and reduces erosion. These facts make it unnecessary to till the field in the fall. If an area has soils which propagate weed infestation, or an impermeable soil layer, chisel plowing can be an alternative to no-tillage for those areas.

\section{SPRING TILLAGE AS PRIMARY OPERATION}

Because the fall tillage as a primary operation in the fallow phase was shown to be a useless operation as compared with no-tillage, tillage in spring became the main concern for many authors. Kıraç (1937) conducted his experiments by using the moldboard plow as a primary tillage tool. He compared this with disc harrowing in March and April to replace the moldboard plowing, the former being less costly than the latter. $\mathrm{He}$ found equal yields and equal soil moisture but different nitrate contents. The amount of nitrate was high in moldboard-plowed plots, because intensive cultivation encouraged microorganism activity which led to rapid and complete decomposition of the wheat stubble. In those years, the wooden plow was common in the Anatolian plateau. The demand to use the moldboard plow instead of the wooden plow (saban) was very high because of its extensive use and popularity in the developed countries. The people advocating the wooden plow were said to be "reactionary" to modern agriculture. Kıraç (1937) handled the issue in a scientific way and tested the moldboard plow, wooden plow and lister as primary tillage implements for three years (1932 to 1934). The lister was preferred because it does similar work to the wooden plow. The results indicated that the wooden plow, contrary to expectations, was not as "dangerous" as a primary tillage tool and produced grain yields as high as the moldboard plow. However, it was stated by the author that it should be converted into an efficient metal tool by agricultural engineers. Gerek (1968) continued Kıraç's experiments on sloping and bottom lands for 18 years and found 1.32, 0.94, 1.00 and $0.99 \mathrm{t} \mathrm{ha}^{-1}$ average grain yields with March moldboard plowing as a control, the wooden plow, lister and cultivator, respectively, on sloping land. Great yield differences between the implements in some years $(1939,40,44,46$ and 48) were not discussed by the author. This makes it difficult to comment on those yield differences. However, Kıraç (1937) observed that the lister and the wooden plow were characterized by tilling the soils shallowly, capturing the severe rainfalls of spring months in the soil and preventing wind and water erosion. As a consequence, we can conclude that the wooden plow and lister can be considered as the right equipment to be used in conservation agriculture and can replace the moldboard plow. On the bottom land, significant differences were not detected between the control (moldboard plow) treatment $\left(1.48 \mathrm{t} \mathrm{ha}^{-1}\right)$ and the wooden plow $\left(1.41 \mathrm{t} \mathrm{ha}^{-1}\right)$. The lister and cultivator yielded 12 and $15 \%$ less than the control treatment, respectively. Dogan et al. (1977) followed the recommendation made by Kıraç (1937) and modified the wooden plow into a metal form (Anatolian saban) which had a steel frame with several shanks. They compared the moldboard plow, the reduced moldboard plow, the metallic saban, Russian-type plow and sweep plow for four years. The modified metallic (saban) plow provided the highest yield in two years out of four and the second highest in the remaining other two years. The sweep plow also provided satisfactory performances. They recommended the Anatolian saban or the reduced moldboard plow as the primary tillage equipment (Dogan and Küçükçakar, 1987). All the research results showed that equipment similar to the wooden plow will do a satisfactory job on the plateau. Mutaf (1970) tested the moldboard plow with a small cutting edge in front, moldboard plows in different forms, the disc plow, the cultivator, and the sweep (Graham) plow for three years at the Polatl State Farm. The highest wheat yield was obtained with the moldboard plow with a small cutting edge in front. The lowest yields were obtained with the cultivator and subsoiling implements. He suggested that the cutting edge plow buries the structureless topsoil deeply and brings well-structured deeper soil to the surface; weeds, pests and organic residue on the surface are also buried deep in the soil, and humus is formed. Contrary to Mutaf's (1970) perception, much of the literature agrees that inverted soils lose their organic matter and structure rapidly (Mannering et al., 1975; Hill, 1990; Lal et al., 1998; Reicosky et al., 1995; Allmaras et al., 2000; Wilhelm et al., 2004). Inverting of soil one in two years in fallow/wheat sequences only postpones the degradation process and does not eliminate or reverse it. As was stated by Reicosky et al. (1995): "it is practically impossible to increase soil organic matter where moldboard plowing is taking place". The present situation on the plateau also shows that our soils lose aggregation and become tiny particles due to low organic matter content (Eyüpoglu, 1999) and primarily excessive moldboard plow tillage. Moldboard plow tillage and different reduced tillage methods were compared in 16 locations in Central Anatolia in the 1971-1977 period (Pehlivantürk et al., 1977). The moldboard plow was recommended for soils with slopes up to $8 \%$. It was suggested that areas in the slope ranges of 3 to $8 \%$ should be plowed perpendicular to the slope direction, and areas with more than $8 \%$ of slope be grazed. Those recommendations deserve some criticism. First of all, this perception did not consider wind erosion, that is not directly related to slope. Secondly, tilling the fields in the central plateau perpendicular to the slope direction is not a practical issue because most of the fields have a long border parallel to the slope direction. The last criticism is that a considerable amount of arable land on the plateau has slopes of more than $8 \%$ and there are no rules or laws acting to restrict the current use of those areas. Thus, the recommended method (moldboard plowing) and current extensive use of it by the farmers is not the right solution and involves none of the conservation measures that would prevent increased water and wind erosion.

The depth of tillage is very important in terms of water and soil conservation. The tilled layer retains more rain water than the untilled layer because of increased soil porosity. On the other hand, it accelerates the mineralization process of soil organic matter through enhanced oxidation. Surface (shallow) 
tillage results in lower soil disturbance and lesser amount of residue incorporation than deep tillage; consequently it leaves more residues on the soil surface (Sprague, 1986). Because the main aim of conservation agriculture is to leave a sufficient amount of plant residue on the seedbed, whatever technology that achieves this can be welcomed. Thus, the moldboard plow operated shallowly during tillage can leave more residues on the soil surface as compared with deep and complete inversion of the soil. Tillage depths were evaluated by several researchers in primary tillage operations in the central plateau. Deep tillage (20 to $25 \mathrm{~cm})$, control $(15 \mathrm{~cm})$ and shallow $(10 \mathrm{~cm})$ were compared in terms of grain yields of wheat (Kıraç, 1937). The results showed that there was no difference between the deep and the control treatments and only a slight $(2.5 \%)$ difference between the shallow and the control. Gerek (1968) tested the same treatments on different dates and in different soil conditions (on bottom and sloping soils) for 18 years. He concluded that shallow $(10 \mathrm{~cm})$ tillage operation in April was superior to the control and the deep treatments on both the slope and the bottom lands. He reported that shallow tillage did not completely invert the soil, resulting in partly buried stubble. He suggested that this greatly prevents wind and water erosion. He also emphasized the fuel economy of shallow tillage and prevention of loss of fertility caused by mixing topsoil with infertile parent material brought up by deep operations in the shallow profile soils common in the central plateau. Berkmen (1961) tested 10, 20 and $30 \mathrm{~cm}$ of primary tillage depths for 7 years and was in favor of depths less than $20 \mathrm{~cm}$. The difference between 10 and $20 \mathrm{~cm}$ was $2.6 \%$ of grain yield on average. Ünver (1978) investigated time, implement and depth of primary tillage operations on soil moisture. Shallow tillage $(11$ to $13 \mathrm{~cm})$ with the reduced moldboard plow and the sweep plow resulted in higher moisture than the moldboard plow. However, in cases of deep tillage $(18-20 \mathrm{~cm})$ the reverse was true. All of the research results we have discussed clearly demonstrate that, contrary to the current common farmers' practices of deep moldboard plow tillage, shallow primary tillage with the sweep plow and reduced moldboard plow, or even with the normal moldboard plow, tends to conserve more moisture than deep moldboard plow tillage, thereby emphasizing the importance of conservation agriculture for the region (Kıraç, 1937; Gerek, 1961; Berkmen, 1961; Ünver, 1978).

\section{SUMMER TILLAGE}

The hot and dry summer period follows intensive spring rainfall on the plateau. Reducing soil moisture loss to a minimum during this period is the most important objective of the summer tillage. Moisture conservation can be achieved by reducing evapo-transpiration during this period. For this purpose, dust mulch and weed control are considered as two important tools. The significance of a surface dust layer (dust mulch) in terms of moisture conservation has always been emphasized when dry farming is the concern. The value of dust mulch was evaluated for moisture conservation. Four years of results indicated that weeds were the only reason for the mois-
Table I. Impact of various tillage and surface management techniques on stored available soil water (in $180-\mathrm{cm}$ profile) at the end of the rainy period (mid-June, 1932) (Kiraç, 1937).

\begin{tabular}{lc}
\hline Types of management & Soil moisture $(\mathrm{mm})^{*}$ \\
\hline Stubble cover & 159 \\
Sand cover & 153 \\
No-tillage + hand weed control & 146 \\
Plow in March at $15 \mathrm{~cm}$ depth & 139 \\
No-tillage + no weed control & 132 \\
Dry plowing at $50 \mathrm{~cm}$ depth & 127 \\
Soil dust (road dust) cover & 95 \\
\hline
\end{tabular}

* Total precipitation during the experimental period was $226.2 \mathrm{~mm}$.

ture loss in fallow areas. Dust mulch caused slightly more (1\%) moisture in the upper $30-\mathrm{cm}$ layer, which can play a significant role in nitrate accumulation and crop emergence. Unfortunately, this extra moisture was not coupled with yield increases (Kıraç, 1937). Similar results were found when dust mulch and chemical weed control (no-tillage) were compared in terms of wheat yield and soil moisture (Karaca et al., 1981). The effects and importance of summer tillage operations in terms of conservation agriculture depend on the previous primary tillage operation on the fallow fields with standing and/or lying stubble. Inversion of soil as a primary tillage on those fields buries all the stubble into the soil. The subsequent tillage (summer tillage) operations will be of little or no value due to the unavailability of the crop residue on the field. Summer tillage research focusing on clean fallow is obviously beyond the scope of this paper (Dogan et al., 1977; Ünver, 1978; Pala, 1982; Dogan and Küçükçakar, 1987; and Güler et al., 1989). However, it is remarkable to see that following the same primary tillage methods, chemical weed control operations outperformed the summer tillage alternatives in terms of yield and net benefits (Tab. II).

\section{ECONOMIC CONSIDERATIONS}

Much of the research on tillage systems was carried out during the 1970s. The price of petroleum was much cheaper, but herbicide prices were very high. Hence, the economic analysis carried out for the tillage systems should be updated. Different tillage systems comprise equipment for primary tillage and a sweep harrow combination and chemical spray for summer tillage; these were tested in five provinces of the Anatolian plateau over five years (Annual Reports of Soils and Crop Managements of Wheat and Training Project, 1972 to 1977). According to the economic analysis (partial budget) on the updated costs and prices, yield losses with sweep tillage and offset disc harrows as primary tillage and chemical sprays as follow-up operations were compensated for by their reduced costs and reached identical profitability with moldboard plow systems (Tab. II). An interesting result was the difference 
Table II. Effects of different fallow tillage methods (primary + summer tillage operations) on average yields, and economic parameters.

\begin{tabular}{|c|c|c|c|c|c|c|}
\hline \multirow[b]{2}{*}{ Yield, cost and benefits } & \multicolumn{6}{|c|}{ Tillage methods } \\
\hline & $\begin{array}{c}\text { Sweep } \\
+2 \text { passes of sweep } \\
+ \text { harrow } \\
\text { combination }\end{array}$ & $\begin{array}{c}\text { Sweep } \\
+2 \text { times } \\
\text { herbicide } \\
\text { sprays }\end{array}$ & $\begin{array}{c}\text { Offset disc } \\
+2 \text { passes of sweep } \\
+ \text { harrow } \\
\text { combination }\end{array}$ & $\begin{array}{c}\text { Offset disc } \\
+2 \text { times } \\
\text { herbicide } \\
\text { sprays }\end{array}$ & $\begin{array}{c}\text { M. Plow } \\
+2 \text { passes of sweep } \\
+ \text { harrow } \\
\text { combination (Control) }\end{array}$ & $\begin{array}{l}\text { M. Plow } \\
+2 \text { times } \\
\text { herbicide } \\
\text { sprays }\end{array}$ \\
\hline Average yields ${ }^{*}, \mathrm{~kg} \mathrm{ha}^{-1}$ & 2118.0 & 2065.0 & 2245.0 & 2101.0 & 2335.0 & 2281.0 \\
\hline Yield differences, $\mathrm{kg} \mathrm{ha}^{-1}$ & 217.0 & 270.0 & 90.0 & 234.0 & 0.0 & 54.0 \\
\hline Costs $^{* *}$, USD ha $^{-1}$ & 250.0 & 233.3 & 291.7 & 275.0 & 333.3 & 283.3 \\
\hline NB diff. from Control & -2.0 & 1.3 & -7.9 & 29.4 & 0.0 & -29.7 \\
\hline
\end{tabular}

* Average of 16 experiments carried out in different provinces of the plateau.

** One pass of $\mathrm{m}$. plow, sweep and offset disc and chemical spray costs 166.6, 83.3, 125.0 and 75.0 USD ha ${ }^{-1}$, respectively.

between tillage and chemical treatments of the moldboard plow. The greater economic benefit of chemical sprays was due to their lower cost (Tab. II). The economic analysis of the trials comparing different conservation tillage methods with the conventional method at a state farm (Altınova, Konya) for three years (Annual Reports of National Wheat Project (Agronomy) for 1971, 1972 and 1973) also showed similar results. Chemical fallow provided 130 to $260 \mathrm{USD} \mathrm{ha}^{-1}$ more profit than the method of conventional fallow. It should be noted that the herbicides used in chemical fallow were contact herbicides and could not control all weeds. Today, we have non-selective, systemic herbicides which control almost all types of weeds. Although we spend more money with the current moldboard plowing than the conservation fallow system, there is no guarantee of obtaining more return with the conventional fallow technology due to crop hazards, e.g., cold, frost and drought, which are becoming more frequent due to climate change. Therefore, Kıraç (1937) formulated a principle for the farming system on the plateau; which may be valid for all dryland production systems. "We need the low cost technologies which may be subject to partial yield loss more than the costly technologies which may have potential yield increase".

\section{NO-TILLAGE}

No-till is defined as planting crops in previous crop residue and unprepared soil by opening a hole, narrow slot, trench or band of the smallest width and depth needed to obtain proper coverage of the seed. This is a single technology to achieve different goals simultaneously; it sustains agricultural production, and protects the environment. It is the most developed conservation agriculture technology, which has many agroecological advantages: controlling water and wind erosion by leaving crop residue on the field surface, increasing organic matter, preventing stubble burning, common on the plateau, and reducing the cost of production and greenhouse gas release to the atmosphere by eliminating tillage. Central Anatolian soils oxidize to two meters, and are friable due to high calcium content and frequent freezing and thawing. Thereby, the physical properties (tilth) expected from tillage occur by themselves under natural processes (Kıraç, 1937). So, we do not see many differences among the tillage methods affecting soil properties and crop yields. This implies that tillage can be easily avoided if stubble and weed problems can be overcome in our soils. No-till fallow (hand weed control) and till fallow plots plowed at various depths as primary tillage and follow-up monthly cultivations were compared for soil moisture contents at drilling time for three years (Kıraç, 1937). No considerable differences were found between primary tillage methods including different tillage depths and no-tillage in terms of soil moisture at drilling time. Stubble mulch on till or no-till plots increased the amount of moisture stored and surface moisture. In dry years, no-till provided higher wheat yields than tilled plots, and vice versa in wet years. Soil moisture at $30 \mathrm{~cm}$ is less in no-till than tilled plots (Kıraç, 1937). This research clearly shows that if the weeds are controlled, no-tillage can replace the conventional fallow system. If straw was spread on the no-till plots (straw mulch), more soil moisture would be accumulated than in the conventional system. The results of only one season (1935/36) in which the soil was not frozen and allowed rainwater penetration into deeper zones show the effect of surface conditions (Tab. I). In a three-year experiment, Kıraç (1937) observed deeper penetration of precipitation into the soil profile with no-till and residue-covered plots than tilled plots. The soils of no-till plots froze later and to a shallower depth and kept water longer than tilled plots. They were more effective in terms of moisture storage than hand-weeded control plots and plowed stubble cover and showed the benefit of conservation agriculture. The no-till system will play a vital role in preventing common stubble burning, reducing tillage costs by $30 \%$ and reducing soil and water loss. The research at the Altınova State Farm (annual reports for 1971, 1972 and 1973) showed that chemical fallow was more profitable, with the net benefit amounting to $260 \mathrm{USD} \mathrm{ha}^{-1}$ more than tillage systems. The research conducted by the CRIFC produced informative results on what the type and the structure of planting machines should be in terms of suitability for the Anatolian region for the success of the no-till system. As a result, two types of drills were developed. Studies on conservation agriculture and no-till started in 1998 and are ongoing. The seven years of research showed that the grain yields of wheat 
were similar in no-till and till systems; however, the cost of notill was $50 \%$ less (134.5 USD ha ${ }^{-1}$ ) than the cost of a tillage system in fallow/wheat rotation (Avc1, 2005 and unpublished data). Similar results were also attained with a legume/wheat system. The Dutch Ankara Embassy supported no-till activities for the transfer of this technology to the Central Anatolian farmers during the 2003-2007 period. We conducted on-farm field trials and field demonstrations and farmer training during this period. In a village (Çeltikli-Haymana), the benefit from no-till (chemical fallowing) was 37\% more than the farmers' system (clean fallow). This went up to 53\% with the use of the improved wheat cultivar Ikizce96 instead of an existing variety, Bezostaya1. In another test area (Temelli-Ankara), no-till vetch hay was $1240 \mathrm{~kg} \mathrm{ha}^{-1}$ and $23 \%$ more than tillage vetch hay production. At the Polatl State farm vetch (hay) and lentil yields were $0.5 \mathrm{t} \mathrm{ha}^{-1}(12 \%)$ and $0.45 \mathrm{tha}^{-1}(27 \%)$ more than the yields obtained from tillage systems. Two farmers in Bala and in Yerköy with large areas of land were in favor of the no-till system when they saw the benefits in the extremely dry season of 2006/2007 (project reports of 2003, 2005 and 2007). They would like to extend the cooperation with research people and planned to plant a considerable amount of land with no-till systems. Similar climates to that of the plateau where conservation agriculture is well documented are in southern Australia and in the Pacific Northwest (PNW) of the USA. It will be instructive to use the experience of those regions in conservation agriculture. In southern Australia, the main elements in the conservation agriculture systems of direct drilling and stubble retention have been widely promoted. The benefits of conservation agriculture systems, which are reductions in erosion, increase in soil fertility, improvement in soil surface physical characteristics, and reduction in soil loss and bulk density, are well recognized (Poole, 1987; Steed et al., 1994). Despite these benefits the adoption process has been considered slow although about $36 \%$ of farmers in southern Australia use no-till and $80 \%$ retain stubble to some extent. The main reason for slow adoption is the expectation that the yield of crops in these systems will not increase relative to conventional systems; however, results from field experiments show that yields of wheat with conservation agriculture may be either higher or lower than with conventional tillage, and that there is considerable year-to-year variation both within and between sites (Kirkegaard, 1995). Conservation tillage in the PNW, like southern Australia, has been greatly influenced by soil degradation (Sojka and Carter, 1994), but particularly by the high rates of erosion and the need for water retention in the drier areas. Freeze-thaw events and the associated problems with soil water storage and erosion have also been drivers in the adoption of conservation agriculture practices in the PNW. Like southern Australia, the rates of adoption have been low. In 2002, just $27 \%$ of the cropland in the states of the PNW was managed with conservation agriculture, and only $7.5 \%$ was managed with no-till systems (CTIC, 2004). The constraints to adoption are similar to those mentioned for southern Australia, with the exception of concerns over inadequate seed zone water for crop establishment under conservation agriculture. In the PNW, early seeding, often ahead of the first substantial winter rains, is vital for early establishment of the win- ter wheat to ensure adequate winter survival. The experience of the PNW and southern Australia in conservation agriculture shows that the main driving force in the adoption of conservation and no-tillage technologies was to obtain more yield or more returns with conservation than with conventional technologies. We are at the beginning in the adoption of conservation agriculture for the Anatolian plateau. Farmers do not have sufficient information on the concept of conservation agriculture. Environmental indicators (erosion, flood) are not taken seriously by farmers. The growing concern regarding erosion problems amid intellectual circles and some NGOs such as the TEMA Foundation is focused mainly on the non-agricultural sites (rangeland and forest).

\section{CHALLENGES AND IMPLICATIONS}

Efficient and sustainable agricultural production requires that we continue to strive for systems that are efficient in their sustainability. In semi-arid regions of our country, conservation agriculture should be considered the primary standard by which systems and practices have been compared. Reduced productivity of our soils due to soil erosion, frequent tillage, intensive crop production and residue removal can be eliminated by reduced tillage systems. For example, previous research on tillage unanimously emphasizes no-tillage in the fall. For spring (primary) tillage, the Anatolian saban and the reduced moldboard and chemical fallow (no-tillage) outperformed in most of the experiments. However, there is not enough information about the residue levels and surface conditions in most of the studies. Therefore, studies on the amount and the state of crop residue (standing or lying of straw or stubble), and on the soil, water and crop yields are required for future research. On the plateau, demand for stubble grazing has been reducing because intensive animal production is replacing extensive systems. On the other hand, most of the straw is left in the fields besides the standing stubble in highyielding years. Consequently, we have a chance to use the crop residue to improve and protect our soils. Some of the research (Karaca, 1987; Güler et al., 1989) highlighted the grassy weed population increase with reduced tillage and its control by the moldboard plow. Problems with grassy weeds can be overcome when we understand the weed biology. Seeds of downy brome buried five $\mathrm{cm}$ or more in the soil cannot emerge and only $1 \%$ survived after two years (Wicks et al., 1971; Durutan, 1982). Some of the chemical herbicides, metribuzin and diclofob, were found effective in control of downy brome (Durutan, 1982). New herbicides, Attribut (a.i. propoxycarbazoneNa) and Monitor (a.i. sulfosulfuron.), to control grassy weeds involving downy brome have been produced and they are effective when following the manufacturer's instructions. IPM (integrated pest management) research, which takes into consideration crop rotations, herbicide application and agronomic practices, is needed for grassy weed control in the dryland plateau. The unavailability of good drills which can perform well in high residue conditions was the main obstacle to obtaining high yields with reduced tillage methods in the past. In order to facilitate drilling with the available seed drills, 
chemical fallow fields were tilled prior to seeding to prepare a good seedbed. The performances of the available drills in notillage agriculture are very critical to the adoption of no-tillage agriculture by farmers on the plateau. Most producers will want to use machinery that is already owned. Some small modifications to the current drills by attachment of cutting disks should be tried in the fall and the spring plantings. Because the soil is very soft and swollen, the spring planting seems more feasible than the fall planting and also important for the implementation of no-tillage. Purchase of additional equipment adds significant costs unless it can be charged against production costs over enough hectares and years. The practical benefit of slightly more moisture in the upper zone of clean fallow than reduced tillage at planting time was not studied in detail. The interpretation was about the potential benefit on the germination and emergence and seedling failure "ala tav" after planting (Kıraç, 1937; Pala, 1982). However, the research on crop emergence and its pre-winter development is very limited in the region.

Acknowledgements: I gratefully acknowledge all the people who conducted or participated in the previous research activities mentioned in this paper, and also respectfully remember those who have passed away.

\section{REFERENCES}

Allmaras R.R., Schomberg H.H., Douglas C.L., Dao T.H. Jr., Campbell C.A., Lafond G.P., Zentner R.P., Biederbeck V.O. (2000) Soil organic carbon sequestration potential of adopting conservation tillage in US croplands, J. Soil Water Conserv. 55, 365-373.

Avcı M. (2005) Zero and minimum tillage as alternatives to conventional cultivation in dryland fallow/wheat and annual cropping systems in Central Anatolia, in: Pala M., Beukes D.J., Dimes J.P., Myers R.J.K. (Eds.), Management for improved water use efficiency in the dry areas of Africa and West Asia proceedings of a workshop organized by Optimising Soil Water Use Consortium (OSWU), 22-26 April 2002, Ankara, Turkey, Aleppo, Syria, ICARDA, and Patanchero, India, CRISAT, pp. 89-101.

Ayday E. (1980) Eskişehir yöresinde anız yakmanın su erozyonuna etkileri. Eskişehir: Eskişehir Bölge Topraksu Araştırma Enstitüsü Müdürlüğü Yayınları, Genel yayın 154, Rapor yayın 113, pp. 1-40.

Aydemir H. (1975) Bala koruyucu orman şeritlerinin mikroklima ve tarımsal ürün verimlerine etkisi, Ormancılık Araştırma Enstitüsü Teknik Bülten 68, Ankara, pp. 1-40.

Berkmen N. (1961) Ankara Zirai Araştırma Enstitüsü Çalışmalarından: 1931-60, Tarım Bakanlığı Ankara Zirai Araştırma Enstitüsü sayı 4 pp. 1-68.

Beşkök T. (1957) Koruyucu orman şeritleri ve Bala'da koruyucu orman şeritleri tesisi denemeleri, Ormancılık Araştırma Enstitüsü Teknik Bülten 7, Ankara, pp. 1-21.

Beşkök T. (1966) Trakya Bölgesinde rüzgar zararlarını önlemek maksadıyla yapılacak ağaçlandırmalar hakkında ön etüt raporu, Ormancılık Araştırma Enstitüsü, Teknik Raporlar 9, Ankara, pp. 1-32.

Carter M.R. (1994) Conservation tillage in temperate agroecosystems, Lewis, Boca Raton, p. 390.

Christiansen-Veniger F. (1973) Türkiye'de Tarla Kültürünün Temelleri, Mentep Matbaası, İstanbul 2, Bask1, pp. 185-194.

Cogle A.L., Strong W.M., Saffigna P.G., Ladd J.N., Amato M. (1987) Wheat straw decomposition in Subtropical Australia II, Effect of straw placement on decomposition and recovery of added $15 \mathrm{~N}$ urea, Aust. J. Soil Res. 25, 481-490.

CTIC (2004) National crop residue management survey: 2002 results, Conservation Technology Information Centre, West Lafayette, http://www.ctic.purdue.edu/CTIC/CRM.html.

Doğan O., Cimilli B., Gücer C. (1977) Orta Anadolu iklim koşullarında nadas-buğday tarım yönteminin uygulandığ 1 yörelerde en uygun sonbahar, ilkbahar ve yaz toprak işleme aletleri ile bu aletlerle uyuşabilen mibzer çeşitlerinin saptanması üzerinde bazı araştırmalar, Merkez Topraksu Araştırma Enstitüsü, Yayın 45, Araștırma Rapor 12, pp. 1-45.

Doğan O., ve Küçükçakar N. (1987) Kuru tarım yönteminin uygulandığı yörelerde en uygun bazı agro-teknik önlemler, Türkiye Tahıl Sempozyumu Kitabı, 6-9 ekim 1987 Bursa TUBITAK-TOAG, Uludağ Üniversitesi, pp. 39-49.

Durutan N. (1982) Orta Anadolu Buğday Ekim Alanlarında Brom (Bromus tectorum L.) 'un Yayılıșı, Biyoekolojisi ve Mücadele Olanaklarının Araştırılması (B. tectorum, survey, bioecology, control measures), A.Ü. Fen Bil. Ens. Yay, No: Bitki Koruma $6(\mathrm{PhD})$, pp. 89-105.

Eyüpoğlu F. (1999) Türkiye Topraklarının Verimlilik Durumu, T.C. Başbakanlık Köy Hizmetleri Gn. Md., Toprak ve Gübre Araştırma Enstitüsü Yayınları, Gn. Yayın 220, Teknik Yayın T-67, Ankara, pp. 5-75.

Gerek R. (1968) Dryfarming İstasyonu Tarafından Yapılmış Olan Nadas Hazırlama ve Toprak Verimliliği, Neşriyat 6, 1-40.

Güler M., Durutan N., Karaca M., Avçin A., Avc1 M. (1989) Increasing WUE through fallow soil management under Central Anatolian conditions, in: Harris H.C., Cooper P.J.M., Pala M. (Eds.), Soil and crop management for improved water use efficiency in rainfed areas, Proc. Int. Workshop, Ankara, Turkey, pp. 76-84.

Hans Johaim Spath (1975) Soil erosion and soil moisture balance in dry steppe climates with cold winters (as illustrated by the example of Central Anatolia), Geo Abstracts A6, 75A/2064.

Hill R.L. (1990) Long-term conventional and no-tillage effects on selected soil physical properties, Soil Sci. Soc. Am. J. 54, 161-166.

Karaca M. (1981) Nadas Toprak Islemesi Derinlik ve Yontemlerinin Infiltrasyona Etkileri, Ankara, Turkiye: A.U. Z.F, Doktora Tezi, pp. $45-55$.

Karaca M., Güler M., Pala M., Durutan N. (1984) Orta Anadolu'da Nadas Alanlarında Uygun Toprak Hazırlığ 1 , in: Kuru Tarım Bölgelerinde Nadas Alanlarından Yararlanma Sempozyumu, 28-30 eylül, 1981, Ankara: TUBITAK Yayınları 593, TOAG 119, pp. 113-122.

Karaca M., Güler M., Pala M., Durutan N., Ünver I. (1987) Orta Anadolu Bölgesinde Nadas Toprak isleme yöntemlerinin buğday verimine etkileri, in: Yürür N. (Ed.), Türkiye Tahıl Sempozyumu 6-9 ekim 1987, Bursa, TMO matbaas1, pp. 29-39.

Kıraç N. (1937) Eskişehir'de Dryfarming Araştırmaları, Dryfarming Deneme İstasyonu, İstanbul Teknik Belleten 1, İstanbul Devlet Basımevi, pp. 10-60.

Kirkegaard J.A. (1995) A review of trends in wheat yield responses to conservation cropping in Australia, Aust. J. Exp. Agric. 35, 835848.

Kramer L.A., Meyer L.D. (1969) Small amount of surface mulch reduce soil erosion and runoff velocity, ASAE Transactions 12, 638-645.

Lal R., Kimble J.M., Follett R.F., Cole C.V. (1998) The potential of US croplands to sequester carbon and mitigate the greenhouse effect, Ann Arbor Press, Chelsea.

Lattanzi A.R., Meyer L.D., Baumgardner M.F. (1974) Influences of Mulch Rate and Slope Steepness on Interrill Erosion, Soil Sci. Soc. Am. J. 38, 946-950. 
Mannering J.V., Giriffith D.R., Richey C.B. (1975) Tillage for moisture conservation, Am. Soc. Agr. Eng., Paper No. 75-2523.

Meyer L.D., Wischmeier W.H., Foster G.R. (1970) Mulch rate required for erosion control on stepped slopes, Soil Sci. Soc. Am. Proc. 34, 928-931.

Mutaf E. (1970) Buğday ziraatında toprak işleme ve problemleri. In: Türkiye'de buğday yetiştiriciliği ve problemleri sempozyumu, 2830 nisan 1969, TUBİTAK. TOAG, sayı:8, pp. 1-150.

MWPS-45 (Midwest Plan Service Committee) (1992) Conservation tillage systems and managements: crop residue management with no till, ridge-till, mulch till, 1st ed., Agricultural and Biosystems Engineering Dep. Iowa State Univ. Ames IA50011-3080.

Özbek H., Dinç U., Güzel N., Kapur S. (1976) Çukurova Bölgesinde anız yakmanın toprağın fiziksel ve kimyasal özellikleri üzerine etkisi, TUBITTAK, TOAG No: 182 Ankara. pp. 3-5.

Pala M. (1982) Yaz Toprak İşleme Derinliklerinin ve Kullanılan Araçların Toprakta Nem ve Sicaklık Değişimlerine Etkileri Üzerinde Bir Araştırma. Ankara: Ankara Üniversitesi Ziraat Fakültesi, Doktora Tezi, pp. 13-71.

Palm C.A., Noordwijk M. van, Woomer P.L., Alegre J.C., Castilla C.E., Cordeiro D.G., Hairiah K., Kotto-Same J., Moukam A., Parton W.J., Ricse A., Rodriguesl V. (2000) Carbon losses and sequestration potentials of alternatives to slash and burn agriculture, in: The biology and fertility tropical soils, TSBF, Nairobi.

Pehlivantürk A., İzgin C.N., Güler M., Ünver İ., Pala M. (1977) Orta Anadolu 1970-1976 buğday toprak hazırlığı ve yetiștirme tekniği araştırmaları Orta Anadolu Bölge Zirai Araştırma Enstitüsü yayınlar1, Yayın No: 77-2, pp. 5-15.

Poole M. (1987) Tillage practices for crop production in winter rainfall areas, in: Cornish P.S., Pratley J.E. (Eds.), Tillage New Directions in Australian Agriculture, Inkata Press, Melbourne, pp. 24-47.

Reicosky D.C., Kemper W.D., Langdale G.W., Douglas C.W., Trinsoutrot I. Jr., Recous S., Mary B., Nicolardot B., Rasmussen P.E. (1995) Soil organic matter changes resulting from tillage and biomass production, J. Soil Water Conserv. 50, 253-261.
Sanchez P.A., Jama B.A. (2000) Soil fertility replenishment takes off in east Southern Africa. Paper for International Symposium on Balanced Nutrient Management Systems for the Moist Savanna and Humid Forest Zones of Africa, Cotonou, Benin, October 9, 2000.

Sanchez P.A., Buresh R.J., Leakey R.R.B. (1999) Trees, soils and food security, Philos. Trans. R. Soc. Lond. B 253, 949-961.

Sayın S. (1983) Eskişehir yöresi kuru tarım koşullarında bazı tarımsal uygulamaların su erozyonuna etkileri, Tokat Bölge Topraksu Araștırma Enstitüsü Müdürlüğü Yayınları, Genel yayın No. 58, rapor serisi No. 36, Tokat, 1983, pp. 15-25.

Sojka R.E., Carter D.L. (1994) Constraints on conservation tillage under dryland and irrigated agriculture in the United States Pacific Northwest, in: Carter M.R. (Ed.), Conservation Tillage in Temperate Agroecosystems, Lewis Publishers, Boca Raton, pp. 285-304.

Soykan İ. (1962) Orta Anadolu'da Rüzgar erozyonu, Topraksu sayı:11, pp. 1-26.

Sprague M.A. (1986) Overview in: Milton A., Sprague M.A., Glover B., Triplett B. (Eds.), No tillage and surface tillage agriculture, John Wiley and Sons, 232.

Steed G.R., Ellington A., Pratley J.E. (1994) Conservation tillage in the south eastern Australian wheat-sheep belt, in: Carter M.R. (Ed.), Conservation Tillage in Temperate Agroecosystems, Lewis Publishers, Boca Raton, pp. 231-254.

Ünver I. (1978) Nadas toprak işlemesinde zaman, derinlik ve yöntemlerin toprağın rutubet ve sicaklık değişimlerine etkileri, A.Ü. Ziraat Fakültesi Toprak bölümü, Doktora Tezi.

Wicks G.A., Burnside O.C., Fenster C.R. (1971) Influence of soil type and depth of planting on downy brome seeds, Weed Sci. 19, 82-86.

Wilhelm W.W., Johnson J.M.F., Hatfield J.L., Voorhees W.B., Linden D.R. (2004) Crop and soil productivity response to corn residue removal: a literature review, Agron. J. 96, 1-17. 